\title{
Abhishiktananda (Henri le Saux, O.S.B) 1910-1973: Pioneer of interspiritual mysticism
}

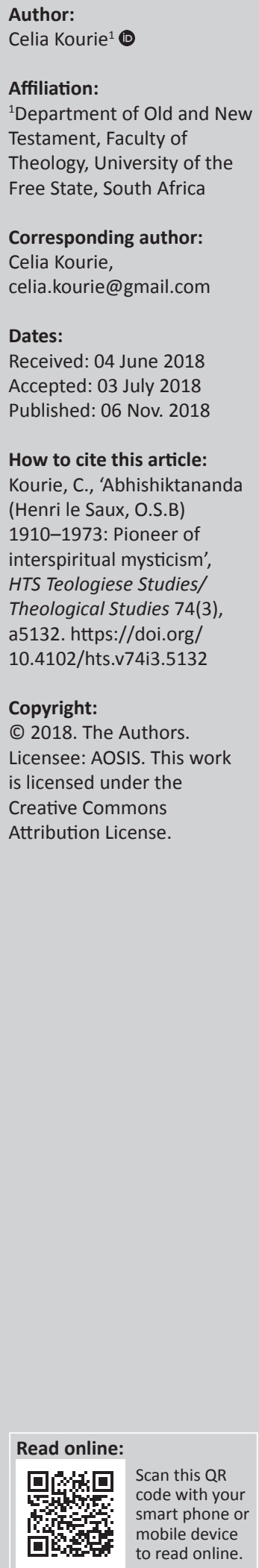

There is no doubt that we live in an interspiritual age, although this is not unequivocally accepted in all sectors of religious and non-religious discourse. However, although, in the past, theological debate was primary, there has now been a welcome shift to shared experience. Interspiritual engagement has as its aim a deep appreciation of, respect for and engagement with the spiritual experience of the 'other'. In order to glean some insights regarding interspiritual mysticism, the aim of this article is to turn to a contemporary mystic for wisdom and guidance: Abhishiktananda (Dom Henri le Saux, O.S.B) (1910-1973) was a French Benedictine monk who left his homeland to live and work in India. Deeply Christian, he nevertheless entered profoundly into the mystical thought of Hinduism. A pioneer of mystical prayer, Abhishiktananda ventured into the realm of advaita, which leads to interior silence. Contemplative silence, in which a state of translucent emptiness occurs, effects a life of unceasing prayer, moment by moment; emanating from the silence of this state of consciousness, compassion, service and energy flow to the benefit of all.

\section{Introduction}

In our pluralistic society, diverse religious traditions offer an opportunity not only for interreligious dialogue but also for interspiritual engagement, which has as its aim a deep appreciation of, respect for and engagement with the spiritual experience of the 'other'. Post-modern spirituality exhibits openness to the deep treasures of the wisdom traditions of the world, bringing with it respect for the other, without abandoning concern for individual and communal diversity. There is a '... more general shift from a static self-referential approach to the Christian life, to a more dynamic or open-ended concept of the spiritual journey' where the 'other' is no longer seen as a threat, which must be avoided, but rather to be welcomed 'as an invitation into a deeper faith' (Barnes 2005:33). ${ }^{1}$

Clearly, the differences between diverse religions relate to particular theological, cultural, religious and sociological parameters, affecting not only cognitive articulation of the tradition but also the very experiences of the adherents. Each is something sui generis - and this particularity is not to be underestimated. It is recognised that there are multiple dimensions and expressions of the sacred; it is therefore possible to be personally tolerant of diversity, while maintaining conceptual differences. However, while respective epistemological foundations may differ, nevertheless, mutual understanding and dialogue will facilitate respect for the autonomy of diverse traditions and enhance mutual enrichment. In addition, the realisation that symbols in diverse religious traditions are tensive and have a cluster of meanings that can neither be exhausted nor adequately expressed by any one referent leads to new angles of vision and a greater global renaissance.

Bearing these considerations in mind, the aim of this article is to consider the life and teaching of Dom Henri le Saux, O.S.B. ${ }^{2}$ (1910-1973), who left his homeland to live in India as a Christian missionary monk; and to consider how his journey into Hinduism effected a profound development in his mystical life. ${ }^{3}$ The question to be considered is as follows: can Henri le Saux be seen as a pioneer of interspirituality, and a bridge between two religious traditions in an era

1.Clearly, this is not a universal phenomenon, as evidenced in even a cursory survey of the history of religious movements. It is not within the purview of this article to enter into discussion of opposing world views in this regard.

\section{Refers to the Order (of) St Benedict.}

3.This article aims to be an Introduction to this Benedictine monk, illustrating elements of his life and thought that shed light on his mystical development as his forays into Hinduism deepened. Several areas of his life and teaching, inter alia, his insights into the Trinity in the light of Sat-Chit-Ananda; the Guru/disciple relationship with Marc Chaduc; the influence of his Guru, Gnanananda, and so on, are not discussed in this short essay. See, inter alia, Friesen, J. 2001. Abhishiktananda's Non-Monistic Advaitic Experience. 
which was not particularly conducive to such an endeavour? To facilitate this enquiry, a preliminary discussion of interspirituality is in order.

\section{Interspirituality}

There is no doubt that we live in an interspiritual age. Although, in the past, theological debate was primary, there has now been a welcome shift to shared experience. ${ }^{4}$ Barnes (2005:32) posits that the emergence of a strong experiential element to the 'more intellectualist' discussion of issues is because of at least four strands in contemporary society: firstly, dialogue with Eastern spirituality; secondly, the contribution of contemplative missionaries; thirdly, public displays of interspiritual encounter; ${ }^{5}$ and fourthly, shared social concerns and commitment to social action. ${ }^{6}$

The global consciousness that is a feature of contemporary spirituality enables a shift from divergence to convergence and effects a 'remarkable richness of spiritual wisdom, of spiritual energies and of religious cultural forms' to come to the fore (Cousins 1985:15). This is all the more important, given the fact that the structural matrix for any given spiritual path can, over the course of time, become primary, and heuristic distinctions between traditions may harden into mutually exclusive descriptive categories, thus prohibiting true dialogue (Kourie 2008:610). 'It may well be that the meeting of spiritual paths ... is the distinctive spiritual journey of our time' (Waaijman 2002:5, footnote 19). However, the fact that spirituality is embedded within certain ideological, cultural and linguistic constructs poses the question as to whether such respective enculturation prohibits true interspiritual encounter? A counterbalance to this question is another: Is it unreasonable to suggest that even incompatible religious beliefs and practices may still share certain aspects of their respective propositional content and mystical awareness as a common element, thus providing points of contact, however tangential these may be? Of course, caution is advocated here; it is vital that the diversity within spiritual traditions is not glossed over. Special attention needs to be given, here, to the importance of language. ${ }^{7}$ Proponents of the contextual or constructivist school of philosophy maintain that it is the essence of

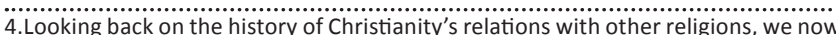
see how far Christianity has come. Historically, four phases have been discerned: the first phase asserted the truth of Christianity and considered other religions the first phase asserted the truth of Christianity and considered other religion untrue; the second phase, from around the 18th century, acknowledged othe religions as natural, whilst Christianity was considered supernatural; in the third phase, arising in the 19th century, Christianity viewed other religions as preparation for fulfilment in the Christian revelation, which was seen as the ape of God's self-revelation; and in the fourth phase, religions are seen to converge, completing one another; each tradition has its particular perspective on ultimate reality, and each has its own contribution to the whole. Interpersonal openness and a willingness to learn from other traditions is a welcome change from colonial and triumphalist approach (cf. Kourie 2011; and also Kourie \& Kurian 2011 which deals in more detail with such issues, particularly with reference to Abhishiktananda).

5.Inter alia: The 1986 meeting of leaders of world faiths at Assisi and the monastic interfaith dialogue (DIM).

6.Inter alia: More active contemplatives, for example, Franco Sottocornola in Japan and Aloysius Pieris in Sri Lanka. The ethical and even political dimensions of interfaith and interspiritual encounter cannot be ignored (Barnes 2005:33).

7.... given the centrality of conceptual frameworks in the determination of our experiences ... to study the basic structures of a people's language is to study, at the very least, that particular people's ontology. (cf. Garside 1972:93-108) language that it is finite and historically relative. Therefore, the use of analogous vocabulary systems cannot be adduced as evidence to support an underlying unity within diverse spiritualities. ${ }^{8}$ The semantic confusion that occurs when contextuality is not given due consideration can cause ontological confusion with respect to the interspiritual exchange. Such concerns have to be taken seriously, without, however, falling into the trap of delimiting the effort to find points of commonality across traditions.

Cousins (2000:89) speaks about the convergence of different mystical and spiritual paths as a communal spiritual journey which has far-reaching consequences for the future of the planet. In his discussion of the second Axial Period, Cousins states that the meeting of diverse religions will result in the emergence of creative energy, which effects a more 'complexified form of religious consciousness'. In a similar vein, Teasdale (2001), a proponent par excellence of interspirituality, strongly emphasises the fact that the sharing of ultimate experiences across traditions is the religion of the third millennium and will lead to a deep sense of community and friendship that cuts across all religious persuasions. Such interspirituality leads to a sense of responsibility towards humanity and the planet. The relevance of the prefix 'inter' in interspirituality is that it 'expresses the ontological roots that tie the various traditions together and that are responsible for religions influencing each other throughout history' (Teasdale 2001:27). The interconnectedness of the entire cosmos is paramount and leads to the realisation that '... through all the diverse forms of spiritual experience and insight we can evolve a higher view' (Teasdale 2001:28). Knitter (1996:169) speaks of the need for a new model for Christians, characterised by of love and respect for those who follow diverse religious paths. Such an inclusivist model is based on the basic Christian commandment to 'love one another'. This is vitally important, given the suspicion of the 'other' that has been a hallmark of many religions for millennia. Although missionary activity has always been intrinsically part of the Christian endeavour, a 'triumphalist ${ }^{\prime 9}$ agenda was often the motive behind such an enterprise. This was also true of Le Saux in his early ministry in India. A brief summary of the main events in his life ${ }^{10}$ will now be offered, followed by an examination of his 'interspiritual' mysticism.

\section{Henri le Saux (1910-1949)}

Born in 1910 at St Briac, Henri le Saux entered a Benedictine monastery, the Abbey of St Anne, in Kergonan, Brittany, in 1929. He is unequivocal with respect to his reason for becoming a Benedictine monk:

What has drawn me [to the Monastery] from the beginning and what still leads me on, is the hope of finding there the presence of God more immediately than anywhere else. (Stuart 1989:3)

8.Katz $(1978,1983,1992)$ is a proponent of this 'constructivist' or 'contextualist' position. 9.Cf. footnote 2 above.

10.See Du Boulay (2005) for a detailed exposition of Le Saux's life. 
His monastic life, while interrupted by military service, ${ }^{11}$ followed a strict regime of prayer, work and study; his responsibilities included being the librarian, the monk in charge of the liturgy and a teacher of the novices. Deeply committed to his Benedictine vocation, nevertheless, from about 1934 onwards, Henri le Saux began to entertain the idea of going to India, a passion which was to grow ever more deeply over the next 12 years. ${ }^{12}$ Although, as a Benedictine monk, Henri le Saux had taken a vow of stability, nevertheless, he was eventually granted his longterm desire to go to India. In $1948,{ }^{13}$ he joined a fellow monk, Jules Monchanin, ${ }^{14}$ at Saccidananda [being,consciousness and bliss] or Eremus Sanctissimae Trinitatis [Hermitage of the Most Holy Trinity], an ashram on the banks of the holy river Kavery in Tamil Nadu, southern India also known as Shantivanam [Grove of Peace]. He took the Indian name, Abhishiktananda. While usually translated bliss of the annointed one also known as Christ, his name can also mean the one who is the joy of Christ, which goes beyond devotion to Christ, to an actual sharing of Christ's experience (Panikkar 1998:19). While the activities of the ashram followed the Benedictine rule, they also incorporated many Hindu customs. Following the path of the sanyasi [renunciate], wearing the kavi [saffron robe], these two missionaries immersed themselves in Indian spirituality, while continuing to serve as Christian ministers. ${ }^{15}$

The aim of these two missionaries was to offer an Indianised Christianity, and clearly, they were influenced by the prevailing triumphalist and/or fulfilment mentality of the age; this was to change dramatically throughout Abhishiktananda's life and experience in India. When not at Shantivanam, he travelled widely and entered more fully into India's culture; his wish being to experience its spirituality for himself. As Du Boulay (2006:23) states: 'In everything Abhishiktananda did while he was in India, the desire for firsthand experience rather than for simply theoretical understanding is central'. On one of his travels, he went to Tiruvannamalai, the Holy Mountain of Arunachala, where he met the Hindu sage, Sri Ramana Maharshi. The impact of this meeting on Abhishiktananda was so powerful that it can be seen as a catalyst in his spiritual journey, deepening what can be called his 'interspiritual mysticism'.

11.Although never seriously involved in the fighting, the memory of throwing his first grenade caused him anxiety. Captured in 1940, he was able to escape on a bicycle before names were taken (Du Boulay 2005:28).

12.Cf. Du Boulay (2005:38-52) concerning this 'irresistable vocation', and the various trials Henri le Saux had to undergo before his dream was realised.

13. His arrival came after India's independence, the problems of the partition of India and Pakistan, and the assassination of Mahatma Ghandhi by a Hindu fanatic (Du Boulay 2005:53).

14.A pioneer of 'inculturation', which was not readily accepted by many ecclesiastics in 1948, Jules Monachin was a gifted intellectual, but chose to be a pastor for the Tamil people; however, he was dedicated to the idea of Christian contemplation in an Indian form (Du Boulay 2005:48)

15.Du Boulay (2005:49) comments on the pioneering spirit of Monchanin and Abhishiktananda, 20 years before Vatican II (1962-1965). The latter began the process of opening up to interfaith and interspiritual encounter.

\section{Abhishiktananda (1949-1973): Interspiritual mysticism Influence of Ramana Maharshi}

Meeting Ramana Maharshi was to impact powerfully the remainder of Abhishiktananda's life. ${ }^{16}$ This encounter was in Abhishiktananda's (1979) own words:

... a call which pierced through everything, rent it in pieces and opened a mighty abyss ... New as these experiences were, their hold on me was already too strong for it ever to be possible for me to disown them. (p. 9)

Sri Ramana Maharshi (1879-1950), a great mystic, was born in Tamil Nadu, India. At the age of 16, he left home for Arunachala, a mountain at Tiruvannamalai, and lived there for the rest of his life. As one of the most sacred mountains in India, Arunachala, which means 'dawn-coloured mountain', is identified with Siva, the Supreme Lord. Ramana recommended self-enquiry as the fastest path to liberation and maintained that the purest form of his teachings was the powerful silence which radiated from his presence and quietened the minds of those attuned to it, bringing them to an awareness of the Divine Reality within. He gave verbal teachings only for the benefit of those who could not understand his silence. Although not a yogi in the conventional sense, pilgrims started coming to his cave on the mountain of Arunachala, just to be in his presence. This led eventually to the ashram at Tiruvannamalai, ${ }^{17}$ which to this day attracts many pilgrims, including a large number of Westerners. Abhishiktananda recognised in Ramana someone '... who embodied the fullness of self-denial, selfactualization, and the wisdom of India' (Egan 2010:353). Abhishiktananda spent periods of solitude in the caves on Mount Arunachala,

... where he underwent an over-powering sense of his inmost self together with the conviction that this self, the deepest core of his being, was ultimately one with the Absolute. (Wiseman 2006:169) $)^{18}$

This mystical mountain drew him back on several occasions between 1952 and 1955. He speaks about the 'gentle whisper' of the mountain, its 'spell-binding wiles' and its 'embrace', which '... will never let him go until he has emptied him of everything in himself that is not the one and only Arunachala ...' (Abhishiktananda 1979:23).

\section{Prayer and advaitic mysticism}

Abhishiktananda's encounter with Ramana Maharshi, and the resultant time spent at Mount Arunachala, impacted his

16.Abhishiktananda visited Ramana twice, before the latter's death in 1950. 'Ramana Maharshi fitted the description of holiness bestowed on Teresa of Avila, for though his influence was far-reaching and profound, he was, in some inscrutable way, "extraordinarily ordinary"' (Du Boulay 2005:67).

17.Abhishiktananda had already visited several Christian and Hindu ashrams before going to Tiruvannamalai. Visits to the latter had to be circumspect, given the suspicion regarding inter-spiritual exchange from many church quarters at the time.

18.See below, Explosion of all concepts: 'Atomic mushroom', for a discussion of the climactic realisation of this oneness, after Abhishiktananda's heart attack in 1973. 
prayer at a deeply personal level, gradually completely changing his understanding of mystical prayer. In the discussion that follows, the following questions form a backdrop to our investigation. What is prayer? Is it possible to 'pray without ceasing'? Is it possible to engage in 'interspiritual' prayer? If so, how will this enrich our understanding of diverse mystical traditions? Will a deeper understanding of the nature of prayer lead to compassion and understanding of the 'other'? What relevance has prayer for the future of humanity and the planet, particularly in the light of the 'eco-crisis' in which we find ourselves? These and related questions are of the utmost importance in contemporary society, divided as it is into innumerable conflicting religious, sociological, political and economic factions. How can Abishiktananda shed light on the nature of prayer?

Always a Christian, Abhishiktananda refers to Jesus' own admonition to his disciples to remain awake and pray (Mk 13:33); his teaching on the contemplative life is also founded on Paul's urging the followers of Jesus to 'pray constantly' (1 Th 5:17) and 'Pray at all times in the Spirit' (Eph 6:18). His small, yet deeply profound, book, Prayer (1967), has become a classic in which Abhishiktananda tells us that to live in constant prayer, to lead a contemplative life, is nothing else than to live in the actual presence of God. Furthermore, 'God is always present to us ... Everything, every being that lives and thinks, does so by sharing in his ${ }^{19}$ being, his divine life and self-awareness' (Abhishiktananda 1967:2). This is reminiscent of the teaching of the 11th century Franciscan mystic, John Duns Scotus, namely that God is being itself, not a being, and all are part of that reality. There is but one: Scotus speaks about the 'univocity of being' - the 'one voice'. Thomas Aquinas tells us that 'Deus est ens' - 'God is Being'. All creation is part of this divine reality - there is only One: God is beyond form, but is manifest in a multiplicity of forms.

Thus, Abhishiktananda (1967) says that contemplation and prayer ought to be the 'very breath' of every disciple of Christ:

The life of prayer, the life of contemplation, is simply to realize God's Presence to us. It is not therefore a special way of life reserved for those few individuals who are called to get away from the world and to dwell in the deserts. Contemplation and prayer ought to be the very breath of every disciple of Christ. (p. 3)

All that has to be done is to 'wake up' to this reality. Each inhalation and exhalation of the breath is prayer itself. Prayer is the natural state of being:

Willingly, unwillingly, consciously, unconsciously, we breathe and go on breathing; continuously air is entering our lungs. So it is with the divine Presence, which is more essential to our life, to our very being, than the air itself which we breathe. (Abhishiktananda 1967:5)

19.Given the use of the masculine pronoun in spiritual writings of the time, no attempt to change Abhishiktananda's lack of gender-inclusive language is made in this article.
Mental images and ideas of God, while of value, can never be the actuality of the divine, but lead '... towards the Beyond, where alone Reality abides in the unfathomable silence of the Godhead' (Abhishiktananda 1967:4).

As a result of Abhishiktananda's meeting with Ramana, and absorbing the teaching of advaita, he entered a deep, heartwrenching period of soul-searching with respect to the Hindu experience of 'realisation' of non-duality. The period between March 1953, his fourth visit to Arunachala, and the end of 1956, when he made a 30-day retreat in complete silence and solitude, can be seen as a time of real spiritual crisis, during which he grappled with the feeling of disloyalty as he 'began to taste the waters of another faith' (Du Boulay 2005:98). In order to plumb the depths of Abhishiktananda's dilemma, let us first look briefly at the notion of advaita.

What is advaita? The primary philosophical exponent of this system of thought in Hinduism is Shankara (788-820 CE), a great visionary, religious organiser and reformer. Basically, according to Shankara, advaita is non-duality. There is only the One: just as the light of the sun is the Sun itself, and the waves in the ocean are the ocean itself, so too the Atman is Brahman. The individual is one with the Absolute. Advaita is a state beyond the world of duality into Oneness. Thus:

One unitive awareness alone exists; it is that One whom we call Brahman, or God. This is the basis of all true religion and all true knowledge. The mystical vision reveals this truth clearly; all that exists is nothing but God. For He is Existence itself. The mystic who experiences identification with God sees all creation as the effusive production of one Consciousness. He realizes the fundamental truth expressed by Shankara, that God alone is the Reality, and He alone is. (Abhayananda 2006:141)

Advaita thus refers to the ultimate experience of 'undifferentiated unity', the oneness of the deepest self (Atman) and the Absolute Reality (Brahman). One, not two. Tat twam asi: you are That, as taught, inter alia, in the Chandogya Upanishad (Mascaro 1965:117-118). 'This takes place in pure consciousness totally beyond all feelings, desires, images, thoughts, and multiplicity ...' (Egan 2010:355).

Abishiktananda avers that only in a higher light can advaita be discerned, not by human reason. Theological speculation and rationalistic arguments will not suffice. Above all, advaita has to be experienced. 'For the man who has direct experience of the Real nothing else remains except the naked uncompounded light of Being itself' (Abhishiktananda [1984] 1997:63). Therefore, advaita means ... 'neither God alone, nor the creature alone, nor God plus the creature, but an indefinable non-duality which transcends at once all separation and all confusion' (Abhishiktananda 1983:98). Abhishiktananda's advaitic insight and experience led him beyond the commonly accepted conventional dualistic notion of prayer to a consciousness beyond rational thought. Nevertheless, as mentioned above, this was not without a considerable level of anxiety. At times, he was afraid that he was exchanging his Christian beliefs and risking his eternal 
salvation for an illusory experience, a 'mirage' (Panikkar 1998:180). This he called the 'advaitic dilemma': was he still genuinely following the Christian path, although he still continued to pray according to his catholic Benedictine heritage? ${ }^{20}$

I am like someone who has one foot on one side of the gulf, and the other on the other side. I would like to throw a bridge across, but do not know where to fasten it, the walls are so smooth. (Du Boulay 2006:32)

Descending deeper into his 'true self', until '... finally nothing was left but he the Only One, infinitely alone, Being, Awareness, and Bliss, Saccidananda. In the heart of Saccidananda, Ihad returned to my Source' (Abhishiktananda 1974:172). Yet again, 'How agonizing it is to be perched on the knife-edge between the opposite slopes of Hinduism and Christianity' (Du Boulay 2005:105).

The dilemma 'gnaws away at his body and mind'. Writing to his friend Raimon Panikkar:

You cannot be torn apart in the depth of your soul, as we are by this double summons (from Advaitin India on one side, and from Revelation on the other) and by this double opposition (from India and the Church, in their ritualism, formalism and their intellectualism) without being lacerated even physically. (Du Boulay 2005:107)

This advaitic dilemma cannot be passed over glibly: as a deeply sensitive mystic, open to the rich experience of nonduality, he expressed the conflict in his diary by confessing that:

he had drunk too deeply of Advaita to return to the 'Gregorian' peace of a Benedictine monk and had enjoyed too much 'Gregorian' peace not to be disturbed by his Advaitic experience. (Egan 2010:354)

Abhishiktananda's forays into the deep mystical insights of Hinduism further convinced him that Christianity was unduly 'fettered by an inconvenient terminology, overly dependent on Hellenistic and scholastic categories'. He argued that a reformulation of Christian mystical experiences within the categories of Vedantic thought and the use of advaitic language would have served many mystics better, particularly in the medieval era, when many were persecuted for their mystical teaching (Wiseman 2006:169). He maintains firstly that the advaitic or pure consciousness experience leads to the 'free gift of self and the mutual communication of love' (Abhishiktananda 1984:176), and secondly, the Christian who awakes from this experience finds herself or himself at a deeper level in the world. There is the realisation that the world is full of value and significance, even at the level of its temporality and diversity, and states of consciousness, however elevated, do not escape their somatic matrix. He teaches that this non-duality transcends all distinction and all 'confusion' between God and the devotee. Thus, because of

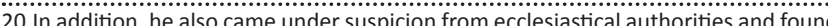
it impossible at times to get church permission to publish some of his works; consequently, much of his work was only published posthumously (Wiseman 2006:169). this inner presence of the divine, it is now possible to discover God in everything (Gianfreda 2008:60): The oneness of all reality is the quintessential mystical insight, and this harmonious unity is available to all:

In the blinding light of this experience there is no conceivable place for any kind of differentiation; there is nothing but a-dvaita, 'not two'. The Christian also is no doubt aware that God is in him and not merely that he comes to him (John 14:23; Revelation $3: 20$ ), and that the very center of his soul is God's dwelling-place. He likewise knows that God is in all things; and in order to meet God, he seeks to plunge deep within himself and all things, in pursuit in his own and their final secret. (Abhishiktananda 1974:63)

As seen in the foregoing, Abhishiktananda did not consider the advaitic experience to be unique to Indian mysticism; referring to John 10:30, he maintained that this non-dual reality was also present in the gospel. The realisation is that the 'self', 'the deepest core of his being, was ultimately one with the Absolute'. Thus, the Christian has to seek for the 'apex' of the soul, where he is an 'I' saying 'Thou' to his God. But going deeper in himself, he realises that his ' $\mathrm{I}$ ' is submerged in the one 'I AM' (Gianfreda 2008:60). This is effected in the 'guha', the 'cave of the heart':

... the Spirit reveals himself in that 'cave of the heart' that so deeply fascinates India ... the last secret of man's own being, the secret that his own origin lies deep within God's infinite love. (Abhishiktananda 1974:100)

One could speak about a 'reality transfer' in the teaching of Abhishiktananda, namely the stimuli of the inner world become invested with the feeling or reality ordinarily bestowed on externals. ${ }^{21}$

Abhishiktananda acknowledges the difficulty of trying to express the inexpressible in language, a constant in mystical discourse:

Of course I can stammer a few words. But that will never be more than some concepts, strictly dependent on my cultural, social, religious and mental environment, on all the previous development of my thought and my consciousness. (Panikkar 1998:371 $)^{22}$

Gianfreda (2008:70) emphasises the importance of Jesus' Selfawakening in the mystical thought of Abhishiktananda. This is of prime importance, for Jesus' awareness of being one with God is 'the fundamental experience of every man who receives the Spirit of Jesus. This is the Christian advaita' (2008:70). Phan (2004:75) emphasises the fact that the inability to come to some reconciliation between the advaita experience and certain Christian doctrines '... did not diminish Abhishiktananda's certitude of the reality and validity of

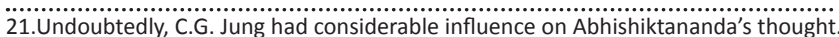
See in this connection Friesen (2001:489ff), who also looks at the influence of Hinduism on Jung.

22.See above footnote no. 7, with respect to Katz $(1978,1983,1992)$. Abhishiktanda's statement would seem to lend weight to Katz's argument. However, with respect to Abhishiktananda's general mystical philosophy, it would be more accurate to to Abhishiktananda's general mystical philosophy, it would be more accurate to
locate his general approach within an essentialist rather than a constructivist position. See Karuvelil (2010) for an interesting critique of Katz' views. 
his experience. He noted, not without enthusiasm: "The experience of the Upanishads is true - I know!"'.

\section{Silence}

Abhishiktananda's emphasis on the value of silence is paramount; he is first and foremost an apophatic mystic. ${ }^{23} \mathrm{He}$ tells us that it is from 'eternal India' that the West can learn the value of the apophatic way, the way of emptiness and quietude:

India has taken with utter seriousness this word that tradition has adopted from Psalm 64: silentium tibi laus: Thy praise is silence. The Christian of the West and of the East, whom a temporary acculturation has all too often cut off from the well-springs of his prayer, must re-learn the silence of the soul before God from eternal India ... Only when the soul has undergone the experience that the Name beyond all names can be pronounced only in the silence of the Spirit, does one become capable of this total openness which permits one to perceive the Mystery in its sign ... ${ }^{24}$ (Abhishiktananda 1983:40-41, 43; cf. Abhishiktananda 1969)

We are reminded here of the Indian mystic, Patanjali, whose meditations on the divine name, the divine sound, OM, lead the yogin beyond intentionality and language by using language to transcend itself. Language is reduced from 'word to sound to conscious silence', and any 'possible cultural or conceptual building blocks' are eliminated (Pflueger 1998:69). The transparent, luminous and most subtle levels of consciousness are progressively stripped away, and speech has:

... returned to its source in conscious silence ... This totally silent, totally inactive witness ... is now isolated in its own unthinkable but conscious luminosity ... (and) sound is reduced to conscious silence, quiescent and seedless Samadhi ... (p. 69)

\section{Abhishiktananda (1984) emphasises that:}

Such silence however is not a self-imposed silence, but a silence, we can say, which is imposed by the Self, the Spirit ... (who) leads man freely and no-one can ever know or ask the Spirit from whence he comes and where he goes. (pp. 117-118)

Lacout (1985:14), writing from his Quaker experience, speaks about silence as 'the grace of inward quiet, of deep peace, of repose in the Light within'. This silence cuts across all religious, ethnic, linguistic, cultural or conceptual traditions; it is pure consciousness (Davis \& Turner 2002:201). The noumenal is contained within the phenomenal. Pacification of the mind effects a new level of inner freedom and from within the silence of a formless state of consciousness flows an abundance of creative energy, resulting in compassion and service:

The true muni is he who has no need to talk either within himself or with others ... The muni is he who has discovered the

23.Language is ontologically impoverished and unable to capture the Reality, which is nothing the divine abyss. Apophasis, meaning 'unsaying' or 'speaking away', nothing, the divice abyss. Apophasis, mrin a 'unsay' subverts the tendency of the mind to arrive at ultimate truth and acknowledges the inaccessibility of the divine. Even the most eloquent language mitigates against disclosure of Reality.

24.'From silence to silence, the "small voices of silence" as Gandhi called it. There comes a day when our silence proclaims more loudly than any words that God is Light, Love and Life' (Lacout 1985:15).
Transcendent with himself and is no longer capable of being before him. 'Ah, ah, ah, Lord, as said Jeremiah, 'I cannot speak' He remains silent. It is finished. (Abhishiktananda 1990:138)

This leads to a translucent emptiness, an inner silence pervading or under-girding ordinary consciousness. Therefore, it is compatible with the normal working of mind and body (Abhishiktananda 1984:117-118). ${ }^{25}$

\section{Explosion of all concepts: 'Atomic mushroom'}

During the final 2 years of his life, Abhishiktananda entered his final phase, namely a 'liberation' or 'explosion,' of all previous concepts. He had already experienced a profound realisation of non-duality, but a heart attack on 14 July 1973 brought all previous experiences to a powerful culmination. He described this as the greatest moment in his life. He wrote to his sister:

It was a marvellous spiritual experience. The discovery that the AWAKENING has nothing to do with any situation, even socalled life or so-called death; one is awake and that is all. While I was waiting on my sidewalk, on the frontier of the two worlds, I was magnificently calm, for I AM, no matter in what world! I have found the GRAIL! And this extra lease of life - for such it is - can only be used for living and sharing this discovery. (Stuart [1989] 1995:308)

His understanding of this coronary attack was that it was an essential aspect of an entire process of grace. In the remaining 5 months of his life, he was too weak to write any more articles or books, but continued to share his experience in his letters ${ }^{26}$ and his Spiritual Diary. Writing to Murray Rogers, he exclaims:

If my message could really pass, it would be free from any 'notion' except just by the way of 'excipient'. The Christ I might present will be simply the I AM of my [every] deep heart, who can show himself in the dancing Shiva or the amorous Krishna! ... The awakening is a total explosion, No church will recognize its Christ or itself afterwards. And precisely for that [reason], no one likes the atomic mushroom. (Du Boulay 2006:198)

The non-dualistic nature of his experiences is reflected in Abhishiktananda's description of being dis-identified with his everyday self: 'Disconnection. All that consciousness with which I usually moved was no longer mine, and yet I myself still continued to be ...' (Du Boulay 2006:202). Furthermore, he had a sense of being beyond space, a-loka, 'To Be, free from all situations, physical, psychological, spiritual or religious ... to find oneself, recover oneself in one's original purity-nakedness' (Du Boulay 2006:202). Friesen (2001:176) makes an interesting observation, namely the fact that Abhishiktananda downplays the grandeur of the experience, because it was being described by some in overly dramatic terms. However, although he did, in fact, try

25. Such silence in the hesychast tradition of Eastern Orthodoxy, as exemplified in the thought of Gregory of Palamas (1296-1359) transfigures not only the inner spirit of the adherent but also the body, so that the whol the adherent but also the body, so that the whole person becomes spirit. Thus, transmutation of consciousness effects transfiguration - known in the Orthodox
tradition as Taborite light - the resplendence of the divine.

26.In particular to his friend, Murray Rogers, who was living in Jerusalem and unable to visit him (Du Boulay 2006:196). 
to minimise his experience, he nevertheless speaks about 'The Awakening' as:

the shining out of the splendor - in splendor ... a brilliance, a light, a glory that envelopes everything, transcends everything, that seizes one and takes one beyond everything. A Sense of 'Beyond' ... of the Beyond. (Du Boulay 2006:203)

It is nothing less than a punctiliar moment of stunning ecstasy and clear realisation of the Real. Clearly, the overwhelming nature of this awakening was primary. In his last letters and reflections, Abhishiktananda illustrates, with profound clarity and joy, the transformation of consciousness that he has experienced, after years of searching, often not without anguish and concern. He has found the 'Grail ... which is basically nothing else than the quest for the Self. A single quest ... It is yourself that you are seeking through everything' (Du Boulay 2005:236). The exquisite joy of finding the Grail radiates through Abhishiktananda's entire being, extremely frail as he was. In this state, he was able to escape from the flux of psychic processes. He moved from fragmented awareness, undergoing a qualitative shift in consciousness:

He was transformed. It was the moment when the lightning struck him, and he died to everything as never before. The mist fell from his eyes and he was able to answer the question he had asked nearly twenty-five years earlier, 'Who am I?'. (Du Boulay 2006:37)

Abhishiktananda had reached the 'Further Shore', where 'he discovered the aloneness of the Alone, and the aloneness of Being, and the joy of BEING, the peace of Being, the freedom of Being' (Abhishiktananda [1975] 1984).

Abhishiktananda died 5 months later, on 07 December 1973. Abhishiktananda's body was buried in the graveyard at the Society of the Divine Word, House of Studies, near Indore. In 1995, his remains were transferred from Indore to Shantivanam and placed next to Bede Griffiths:

Their unceremonious removal (there are no laws against grave digging in India), while understandable in terms of the wishes of the church and the ashram - indeed done with full agreement and participation of Shantivanam - is a source of sadness to his friends, who felt that the most suitable last home for him would have been the Ganges, the sacred river that was so important to him. (Du Boulay 2005:241)

\section{Conclusion}

Abhishiktananda, a pioneer in the way of interspirituality, writer of 12 books, several articles and thousands of letters, was a 'God-intoxicated' follower of Jesus. He broke through the barriers of triumphalist, colonial missionary endeavours, entered into the depths of God's wisdom and found the riches of the Spirit in his encounter with Hinduism. As he tells us in his book the Further Shore, for the one who has discovered his true Self:

there is no longer forest or town, clothes or nakedness, doing or not-doing. He has the freedom of the Spirit and through him the Spirit works as he wills in this world, using equally his silence and his speech, his solitude and his presence in society. (Du Boulay 2006:204)
Having passed beyond his 'own' self, Abhishiktananda found bliss and peace in the Self alone, the real Self, the parama-atman. In his writings, particularly his earlier work, because of his Christian and particularly Benedictine heritage, he was indebted to certain religious traditions but he was not indentured to them. He disavowed stifling religious accretions that hold people hostage, and in his own life became increasingly liberated from all concepts, all myths and simply to be as He is himself in the final mystery of his self-awareness, '... plunged head over heels, completely dazzled' (Du Boulay 2006:194).

Therefore, the answer to the question posed at the beginning of this essay is an unequivocal 'Yes'! Abhishiktananda is an interspiritual, mystical pioneer, contributing to the development of new hermeneutic frameworks and symbolism in his encounter with Hinduism, particularly with respect to the understanding of advaita. Consequently, his influence continues to spread its perfume in a world which so often has a blinkered understanding of life. His message opens up new vistas where diverse spiritual traditions can relate in an atmosphere of reciprocal transparency. Initially, split between two great traditions, Christianity and Hinduism, enduring the anguish of moving into a more enlightened and open approach, he is a beacon of interspirituality for all seeking a more inclusive mystical journey. Remaining faithful to one tradition and at the same time, open to the richness and truths of another, Abishiktananda shows us how to transcend differences between religions and engage in mutual understanding and experiential engagement. Taking us beyond our limited horizons, avoiding the danger of cultural imperialism and epistemological hubris, bringing freedom from strictures, entrenched beliefs and myopic values, Abhishiktananda leads those who are open to his message to an ocean of interconnectedness. His message of living in the still point, the 'I AM,' sacralises daily life, resulting in a powerful, yet often hidden, energy that impacts all aspects of societal living.

\section{Acknowledgements Competing interests}

The author declares that he or she has no financial or personal relationships which may have inappropriately influenced him or her in writing this article.

\section{References}

Abhayananda, S., 2006, The Wisdom of Vedanta, O Books, New York.

Abhishiktananda, 1967, Prayer, S.P.C.K., London.

Abhishiktananda, 1969, 'An approach to Hindu spirituality', Clergy Review 54(3), 163-174.

Abhishiktananda, 1974, 'Experience of God in Eastern Religions', Cistercian Studies 9, 151-152.

Abhishiktananda, [1975]/1984, The further shore, ISPCK, New Delhi.

Abhishiktananda, 1979, The secret of Arunachala, ISPCK, New Delhi.

Abhishiktananda, 1983, Hindu-Christian meeting point: Within the cave of the heart, ISPCK, Delhi.

Abhishiktananda, [1984]/1997, Saccidananda: A Christian approach to advaitic experience, ISPCK, New Delhi. 
Abhishiktananda, 1990, Guru and disciple, ISPCK, Delhi.

Barnes, M., 2005, 'Spirituality and the dialogue of religions', in P. Sheldrake (ed.) The New SCM Dictionary of Christian spirituality, pp. 32-37, SCM Press, London.

Cousins, E., 1985, Global spirituality. Towards the meeting of mystical paths Madras, Radhakrishnan Institute for Advanced Study in Philosophy, Chennai.

Cousins, E., 2000, 'A spirituality for the new axial period', in K. Collins (ed.), Exploring Christian spirituality, pp. 83-91, Baker Books, Grand Rapids, MI.

Davis, O. \& Turner, D. (eds.), 2002, Silence and the word. Negative theology and incarnation, Cambridge University Press, Cambridge.

Du Boulay, S., 2005, The cave of the heart. The life of Swami Abhishiktananda, Orbis Books, Maryknoll, NY.

Du Boulay, S., 2006, Swami Abhishiktananda: Essential writings, Orbis Books, Maryknoll, NY.

Egan, H.D., 2010, Soundings in the Christian mystical tradition, Michael Glazier, Collegeville, MN.

Friesen, J.G., 2001, 'Abhishiktananda's non-monistic advaitic experience', Unpublished $\mathrm{D}$ Litt et Phil. Thesis, University of South Africa.

Garside, B., 1972, 'Language and the interpretation of mystical experience', International Journal for the Philosophy of Religion 3, 93-108. https://doi. org/10.1007/BF00136754

Gianfreda, F., 2008, 'Abhishiktananda's theology of awakening', Religion East and West 8, 55-73.

Karuvelil, G., 2010, 'Mysticism, language and truth', Journal of Dharma 35(3), 259-275.

Katz, S. (ed.), 1978. Mysticism and philosophical analysis, Sheldon Press, London.

Katz, S. (ed.), 1983, Mysticism and religious traditions, Oxford University Press, Oxford.

Katz, S. (ed.), 1992, Mysticism and language, Oxford University Press, Oxford.
Knitter, P., 1996, 'New possibilities for interreligious dialogue', in B. Bruteau (ed.), The other half of my soul. Bede Grifffiths and the Hindu-Christian dialogue, pp. 168-183, Quest Books, Wheaton, IL.

Kourie, C., 2008, 'Mystical consciousness in an interspiritual age', in H. Blommestijn, C. Caspers, R. Hofman, F. Mertens, P. Nissen \& H. Welzen (eds.), Seeing the seeker. Explorations in the discipline of spirituality: A Festschrift for Kees Waaijman on the occasion of his 65th birthday, pp. 609-620, Peeters, Leuven.

Kourie, C., 2011, 'Crossing boundaries: The way of interspirituality', Religion and Theology 18, 10-31. https://doi.org/10.1163/157430111X613647

Kourie, C. \& Kurian, A., 2011, 'Abhishiktananda: A Christian advaitin', HTS Teologiese Studies/Theological Studies 67(3), Art. \#1054, 8p. https://doi.org/10.4102/ hts.v.67i3.1054

Lacout, P., 1985, God is silence, Quaker Home Service, London.

Mascaro, J. (trans.), 1965, The Upanishads, Penguin Books, London.

Panikkar, R. (ed.), 1998, Ascent to the depth of the heart: The spiritual diary (1948-73) of Swami Abhishiktananda (Dom Henri Le Saux), OEIL, Paris.

Pflueger, L.W., 1998, 'Discriminating the Innate Capacity: Salvation Mysticism of Classical Samkya-Yoga', in R.K. Forman (ed.), The innate capacity. Mysticism psychology, and philosophy, pp. 45-81, Oxford University Press, New York.

Phan, P.C., 2004, Being religious interreligiously: Asian perspectives on interfaith dialogue, Orbis Books, Maryknoll, NY.

Sheldrake, P. (ed.), 2005, The new SCM dictionary of Christian spirituality, SCM Press, London.

Stuart, J. (ed.), [1989]/1995, Swami Abhishiktananda: His life told through his letters, ISPCK, Delhi.

Teasdale, W., 2001, The mystic heart. Discovering a universal spirituality in the world's religions, New World Library, Novato, CA.

Waaijman, K., 2002, Spirituality. Forms, foundations, methods, Peeters, Leuven.

Wiseman, J.A., 2006, Spirituality and mysticism. A global view, Orbis Books, New York. 